\title{
Introduction
}

\section{Labour, mobilities and informal practices in Russia, Central Asia and Eastern Europe}

\author{
Rano Turaeva and Rustamjon Urinboyev
}

\section{Introduction: mobility and informality}

Mobility and migration increased rapidly following the end of the Cold War period and the collapse of communist regimes. These developments led to the emergence of new national, regional and international mobility regimes (e.g., the Commonwealth of Independent States, the European Union and the Eurasian Economic Union). These newly established mobility regimes-encompassing visa regulations, union regulations, refugee politics, labour market regulations, migration regulations and capital globalisation-rendered these nation-states visible in new ways and placed state-society relations at the centre of popular discussions (Schiller and Salazar 2013). For many travellers, mobile workers, migrants, refugees and other mobile entrepreneurs moving beyond their hometown or country, these new mobility experiences and strategies generated new challenges, hardships and uncertainties. The social and kinship networks, which served as alternative (to the state's) welfare structures in their home countries, were no longer available in their host countries, leaving individuals in more precarious positions and rather vulnerable (Turaeva 2016). Another key contributing factor was the rapid proliferation of draconian immigration laws and policies within various migration regimes (Coutin 2003; De Genova 2004), a global trend that produced millions of undocumented migrant workers for informal economies.

However, despite tightening immigration laws and flourishing informal economies, legal uncertainty, increased mobility and globalisation, mobile people became increasingly innovative and transnational, whereas a growing number of mobile entrepreneurs have found their niches within and beyond these processes and structures. Since mobility does not recognise rigid state legal systems and boundaries, mobile actors have found alternative ways of navigating restrictive legal landscapes and of organising their economic activities and mobile lives. Today mobile people represent the largest category of people navigating their daily survival through mobile lives beyond nation-state legal systems, crossing multiple geographic and digital boundaries and dealing with diverse power structures, institutions, brokers and gatekeepers. The contributions in this volume include original, fieldwork-based examples from Russia, Central Asia, Eastern 


\section{Rano Turaeva and Rustamjon Urinboyev}

Europe and beyond, dealing with mobilities and informal practices in transnational and digital spaces.

Another key tendency explored in this volume focuses on how informal practices are becoming increasingly transnational due to the explosive growth of communications and transportation technologies. We can no longer confine informal practices to the territory of a single nation-state. In arguing so, in this volume, individual authors show how informality operates across physical and digital boundaries, through varying means and with an identifiable impact on the outcomes of practices that mobile actors (and other actors) engage within their host countries. In other words, the informalisation of societal organisation as well as state-society relations extend beyond national boundaries taking on a transnational and global character.

As the review of informality literature indicates, today we can speak of informal economies and/or practices not only in so-called third-world countries or the Global South but also in the North (Hart 2005; Cassel and Cichy 1986; Tanzi 1980; Roitman 2005; Meagher 2009, 2010). There is, by now, a large body of literature on informal economies, schematically divided into two camps: namely, positive views and optimistic accounts versus negative views with pessimistic accounts (Cassel and Cichy 1986; Tanzi 1980; Tokman 1992; Meagher 2010; Roitman 2005; MacGaffey and Bazenguissa-Ganga 2000). The literature on informal economies primarily focuses on examples from Africa, Latin America and Europe. However, some works also examine the former Soviet space (Ledeneva 1998, 2006, 2013; Mars and Altman 1983; Berliner 1952; Grossman 1977; Treml and Alexeev 1994; Humphrey 1998; Kotkin 1995; Kaiser 1997).

The approach to informality taken in this edited volume contributes to the novel debates falling under the 'mobility turn' (Urry 2012, 2016) within migration studies, based on the understanding that people, things and ideas are in constant and dynamic motion, thereby making the rigid institutional structures, boundaries and legal landscapes blurred within mobile transnational and digital contexts. Salazar (2017: 6) outlines the 'new mobilities paradigm' and states that this paradigm 'incorporates new ways of theorising how people, objects and ideas move around by looking at social phenomena through the lens of movement [...] It can be seen as a critique of both theories of sedentism and deterritorialisation.' Studies of mobility are not a new paradigm but is rather built on a large body of literature, where mobility was approached from very different angles and depths (Giddens 1986; Appadurai 1991, 1996; Beck 2006; Salazar and Schiller 2014; Salazar 2017). Giddens (1986) attempted to capture movements through fluidising the structure in his structuration theory. Appadurai (1991) drew our attention to the processes of deterritorialisation. Beck (2006) emphasised the risks and the constructions of risks and power. Thus, fluidity became a central feature defining mobilities, structured through networks, spaces and orders (Urry 2016; Salazar 2017; Levebfre 2004).

Armed with these perspectives, in this volume, we attempt to shed light on the daily navigational and survival strategies within mobile transnational and digital contexts. As we show in the chapters that follow, in such contexts, institutional 
structures are not rigid, but rather fluid and changing, where various boundaries become blurred and legal systems are no longer able to catch up with the evergrowing mobilities, calling for more informal means of arranging things, getting things done and living mobile lives (Schiller and Salazar 2013).

In what follows, these insights are explored within the context of post-socialist societies in Russia, Central Asia and beyond Eastern Europe. Literature on informal economies focusing on the Soviet era is scant, although some studies have shown that informal economies function in grey zones, between legal and illegal, parallel to the central state-planned economy (Portes and Böröcz 1988; Morris and Barclay 2008; Mars and Altman 1983; Round et al. 2008; Berliner 1952). Some of this literature focuses on shuttle traders (chelnoki/chelnochkovyi biznes) in the late Soviet era (Turaeva 2010; Mukhina 2009; Humphrey 1999; Pohorila and Korzhov 2001; Markova 2014; Cieślewska 2014).

Since the end of socialist regimes, the end of the Cold War and accelerated globalisation, mobility and transnational flows, informal economic activities have increased dramatically, and employment patterns have drastically changed (Nazpary 2002). In many countries of the Global South, economic or social incentives no longer remain in state-provided jobs, whilst welfare was often provided under the socialist or communist promises of those states (Raeymaekers et al. 2008; Hansen and Mariken Vaa 2004; Maloney 2004; Chen 2006).

The empirical examples collected in this volume show that actors living within transnational spaces crossing several national boundaries innovatively respond to the bureaucratic and institutional constraints and invent various informal channels and strategies in order to navigate the repressive legal landscapes which often do not accommodate mobile labour. Trust, transnational networks, digital technologies and informality play crucial roles in the verbal agreements replacing formal contracts (Turaeva 2013, 2014; Urinboyev 2017). Rules governing the economic and social activities of mobile workers are ad hoc and flexible. They can be renegotiated on the spot and are subject to changing circumstances. There are many variables in play across all aspects of the negotiating process, the institutionalisation of new rules and relations, status maintenance, transnational pressures and networks as well as the formation of trust networks (Turaeva 2013; Urinboyev and Polese 2016). These include historical institutional developments and the history of state formation in the region; current economic and political developments, as well as micro-level aspects of daily life, such as social norms and cultural repertoires. These, coupled with the currents of globalisation processes shared via communication technologies as well as other traditional means of channelling information and knowledge, establish frames of ordering or reordering the spaces of transnational economic engagement and living simple mobile lives (Turaeva 2014).

\section{Mobility-deregulation and immigration-reregulation}

Mobility challenges national boundaries and state regulatory systems in both sending and recipient countries or multiple countries relevant to mobile subjects. 
This leads to what has been already observed as deregulation. The economic, political and social lives of mobile persons and migrants in the places of their engagement leads to additional engaged practices, requiring recognition or dealing with locally existing state regulations. The countries where mobile persons or migrants live or work, try their best to exert maximum control over all aspects of migrant lives and the migration processes taking place within the boundaries of the relevant states. This process has been observed by many researchers as reregulation experiences of states facing new forms of mobility and migration, which otherwise stemmed from the desired control over the population within the relevant national boundary. These two processes are unrelated and can only be seen as examples of experiences of mobility and the informalisation of economies, societal relations, politics and security.

Regulation and reordering of transnational spaces received considerable attention where new perspectives were opened going beyond state-centric analysis of rules and rule making (Djelic and Sahlin-Andersen 2006). We suggest examining the nation-state legal systems from the opposite side, namely, through the eyes of individuals who can choose whether to follow state laws or not (Ewick and Silbey 1992, 1998, 2003; Silbey 2005). Rather, taking the opposite perspective on the issue and focusing on how ordinary people construct their 'own legal world' (Marshal and Barclay 2003)—namely, the perspective of mobile people themselves - provides more productive thinking about how these laws and policies shape the actions of those at whom such laws and policies are directed. Mobile actors negotiate their host country's legal system in their own terms and with their own tools, which, in turn, play a part in the process of producing new forms of legal order and informal governance. Thus, mobile actors may produce various informal norms and practices (i.e., 'informal legal orders'), providing alternative (to state law) means to regulate their working lives and to seek redress for their problems.

Accordingly, these new informal orders and practices serve as frames of reference and sources of basic order for transnational mobile actors who negotiate their daily economic survival within and outside their home countries. In relation to the state or redefining the state and negotiating rules and norms represent aspects of these daily survival processes (Djelic and Sahlin-Andersson 2006). Rule making, now subsumed within the debate on transnational governance, is conceptualised more broadly than in its classical definition, which assumed the centrality of the state (Baldwin et al. 1998). Critical approaches to the scholarly works on deregulation pointed out the 'new age of legalism' (Schmidt 2004) and importance of the role of the state. Schmidt (2004) for instance points to both declining states and increasingly important 'age of legalism'. Comaroff and Comaroff (2006: 33) refer to this age as 'an Iron Cage of Legality', in which law fetishism is overdetermined and where 'the distillation of postcolonial citizens into legal subjects, and postcolonial politics into lawfare, charts the road from the past to the future, albeit less sharply in some places than in others. Not only are government and public affairs becoming more legalistic, but so are "communities" within nation-states' (Comaroff and Comaroff 2006: 33). 
Furthermore, transnational regulation was defined as a form of governance which 'structures, guides and controls human and social interactions beyond, across and within national territories' (Djelic and Sahlin-Andersson 2006: 6).

The above discussion on regulation, deregulation, reregulation and transnational governance recognises that the state is not the only governing agency and authority for regulation, such that other actors and sources for authority provide order and norms. From this point of view, nation-state law and regulations merely represent one among many other normative orders within society. Thus, no single, integrated set of rules in any society exists, whether codified into law, sanctified by religion or established as the rules of daily social behaviour. Quite simply, there is no uncontested universal normative code that guides people's lives and actions; the very nature of the legal order is determined by the outcomes of the struggles and the interplay amongst plural normative orders. This conclusion regarding plural forms of regulation and normative orders are well supported by examples from alternative regulations and legal pluralism (Merry 1988; Griffiths 1992; Keebet von Benda-Beckmann et al. 2009; Eckert 2004) as well as the examples offered in this volume.

\section{Uncertainty as a resource: from mobilities to informalities}

Uncertainty is maintained and even fostered for use as a resource for economic gain by those in power-be it the middlemen offering services to avoid the state or state officials acting in the name of the state. Interethnic relations and nationalistic discourse rather strongly shape encounters, particularly when crossing borders (Turaeva 2018). Intensified by the additional uncertainty of the travellers, this creates favourable conditions for violence and abuse.

This environment is precarious, as described by Judith Butler (2009, 2016). Butler (2009: ii) defines precarity as a 'politically induced condition of maximised vulnerability and exposure for populations exposed to arbitrary state violence and to other forms of aggression that are not enacted by states and against which states do not offer adequate protection'. Here, it is important to distinguish between systemic qualities of risk - as in Beck's risk society model (Beck 2009) —and precarity as a structural condition where knowledge of these qualities (precarity and risk) are given. However, in situations of uncertainty, a lack of knowledge about security stands as an a priori requirement for feeling insecure and in doubt (a state of uncertainty). On the individual level, uncertainty-namely, the lack of knowledge about risks - renders one completely dependent upon others and, therefore, vulnerable to violence and abuse. Pelkmans (2013) highlights the intellectual aspect of doubt, whereas McBrien (2013: 253) draws attention to the emotional aspect of doubt. The anthropology of uncertainty (Boholm 2003; Samimian-Darash 2012) is an emerging field of study, and scholarly works on uncertainty and risks remain dominated by quantitative analysis primarily in the fields of medicine, health, business and trade.

Mobilities imply change and always involve novelty if focused on location, people, institutions and rules. Mobilities are, therefore, often connected to a 
positive outcome and moving up the social and economic ladders. However, mobilities as something fluid also denote instability and uncertainty. New locations, new rules, new environments and the absence of familial networks and family support lead to situations of uncertainty and risk unless people are friendly to each other, state officials do not abuse their authority and people are protected by their families and networks. In an environment of precarity, those who have no power depend on the mercy of those in power, feared as capable of abusing their power at any moment. The condition of uncertainty is maintained through, for instance, constant questioning of travellers' belongings, documents and the purpose of travel. Uncertainty is not always viewed as negative, depending upon the actors and if an actor is in a position to make use of the uncertainties of others. Uncertainty represents a significant resource, making it easy to gain profits in the form of money, presents, private numbers and the attention of good-looking women (Turaeva 2018).

Uncertainty and informality represent a married couple, where precarity and uncertainty are related to informal relations and activities producing vulnerabilities. In this volume, we have collected diverse examples of informal practices taking place in the contexts of mobility and migration. These examples show that individuals who live mobile lives must face the consequences of fluidity and the instability of rules, institutions, locations and networks. Flexibility, navigation and entrepreneurship are important skills actors should possess in order to live mobile lives. Constant efforts aimed at stabilising fluidity and change produce temporal orders and spaces as well as effective networks of trust, where individuals attempt to deal with the challenges of mobile living and uncertainty.

\section{Volume overview and chapter outlines}

This volume is organised in three sections, which focus on three interlinked themes: (a) labour, (b) mobility and (c) informality. The three sections may overlap in terms of their contents; however, our aim is to emphasise the central themes which cut across the chapters of this volume. The chapters highlight the ways in which mobile actors and entrepreneurs organise and negotiate their daily precarious livelihoods, navigating the multiplicity of rules, institutions, locations and networks within national, transnational and digital landscapes.

\section{Part I: Labour in times of uncertainty}

The chapters in this section explore how mobile actors and non-citizens deal with legal uncertainty, unequal power relations and precarity under the conditions of uncertainty, undocumentedness, a weak rule of law and a shadow economy. All four chapters demonstrate that the condition of legal uncertainty and precarity produces varying outcomes in different social contexts and arenas. On the one hand, such circumstances may indeed lead to unequal power relations and arbitrariness in decision-making. On the other hand, however, some actors can make use of this uncertainty as a resource and opportunity to 
structure navigation through the legal restrictions or to gain access to facilities and resources otherwise difficult to obtain within the official legal framework of their host country. Flexibility, navigation, street smartness and the ability to adjust to a weak rule of law environment and corrupt system represent important traits and skills actors need to possess when dealing with the challenges of mobile living.

Nikolaos Olma in his chapter, drawing on ethnographic fieldwork in Uzbekistan conducted between 2014 and 2016, examines the informal practices and experiences in the (informal) taxi sector in post-socialist Tashkent, which serves as a primary income-generating arena for many unemployed internal migrants originating from Uzbekistan's rural areas. Taxiing is a quintessentially informal activity in Uzbekistan, given that it is not only a precarious profession practised outside the institutional and legal boundaries of the Uzbek state and its agencies but is itself also informed by multiple modalities of informality permeating the subjectivities and the everyday lives of the drivers involved in it. From acquiring a car to finding their way around the city to escaping regulatory pressure and paying bribes to traffic police officers and tax agency officials, informal taxi drivers continually navigate a wide array of informal processes, negotiate power relations, adjust to market forces and manoeuvre around various legal frameworks. The involvement of rural labour migrants in taxiing further exacerbates this informality given the informal character of most actions and activities pertaining to the settlement and employment of these individuals in Tashkent. In this sense, Olma examines the informal taxi as an index of how and where two seemingly independent mobility paradigms - that is, rural-urban labour migration and informal urban transportation - converge. Thus, Olma uses the informal taxi sector as a lens through which he explores the various informal processes and everyday livelihood strategies rural labour migrants employ in their attempts to deal with the uncertainty and precariousness accompanying relocation to Tashkent.

Round and Kuznetsova's chapter on the labour relations of Russian businesses and other employers with migrant workers describes the daily struggles of migrants who attempt to formalise their work despite continuous barriers established by employers more interested in abusing the precarious existence of migrants. In doing so, Round and Kuznetsova show that even those migrants who possess all of the necessary papers and permits to work legally face difficulties securing work based on contracts, which employers avoid. This chapter provides a theoretical contribution to discussions regarding uncertainty as a resource and power relations within labour markets and the state regulation of labour markets.

Turaeva and Amon's contribution on deportation regimes in Russia illustrates the consequences of the legal regulation of a deportation regime, namely, the new regulation adopted after 2012, which granted the police and courts as well as others even more power over the unprotected migrant population in Russia in order to abuse the system of deporting migrants. Here, the authors describe contradictory statutes within Russian law used to establish a deportation regime in order to remove unwanted migrants. This chapter also contributes to discussions of how 
uncertainty is used as a resource by those in power to abuse migrants by rendering them easily deportable.

The last chapter in this section by Voivozeanu explores the informality within the transnational labour market revolving around the recruitment process (or posting) of Romanians who work in the German construction and meat processing sectors. This migration infrastructure of posting involves numerous actors, namely, companies that facilitate posting, migration intermediaries, migration networks and migrants, who actively make use of grey zones and informal practices, creating transnational spaces that often do not fit within legal systems. As this chapter shows, in the context of the current European regulatory framework, the social fields created by posting are filled with informal norms and structures through which the actors involved negotiate across borders. Within recruitment for this type of employment, formal actors (typically, companies) rely on informal actors and practices to recruit workers and remain on the market. Arrangements which involve agents and/or networks might be beneficial for migrants, since they may bring (better) employment opportunities. Yet, they might reproduce power relations in favour of those actors controlling the recruitment process, thereby leading to exploitative contexts for workers. As a result, closely examining the entire migration process, where diverse actors develop both formal and informal relations and practices, it becomes difficult to differentiate between formal and informal arrangements amongst companies, agents and migrants.

\section{Part II: Mobility as blurring legal, physical and digital boundaries}

The four chapters in the second section of this volume all illustrate the ways in which mobility blurs all kinds of boundaries such as legal, informal, physical or geographic, digital or real world. As a result, rigid institutional structures, physical boundaries and legal landscapes become blurred within mobile transnational and digital contexts. Mobile actors, drawing upon their premigratory cultural legacies, practices and social capital, negotiate and redefine the rules and norms and innovatively navigate bureaucratic, institutional and legal constraints within national, transnational and digital contexts. These navigational strategies serve as an alternative adaptation venue, enabling mobile actors to organise their precarious livelihoods in repressive legal environments.

These processes are vividly illustrated in Urinboyev's ethnographic study of smartphone transnationalism amongst Uzbek migrant workers in Russia-a migration context characterised by a weak rule of law, malfunctioning institutions, large shadow economies, a poor human rights record, widespread xenophobia and a weak civil society. Hence, given the restrictive sociopolitical environment, corrupt legal system and widespread xenophobia, Uzbek migrants in Russia can hardly engage in collective action or transnational activism and instead attempt to minimise their visibility in public places (e.g., parks, streets, shopping malls and on public transport). Although Uzbek migrants' transnational activism and diasporic identities are barely visible in public places, rapid improvements in 
communications technologies (e.g., smartphones and social media) have enabled Uzbek migrants to remain in touch with their home societies, as well as create efficient, smartphone-based translocal communities in Moscow, typically centred around migrants who hail from the same neighbourhood community or village in Uzbekistan. The existence of this smartphone-based transnational environment helps migrants cope with the challenges of musofirchilik (being alien) and avoid or manoeuvre around structural constraints such as complicated residence registration and work permit rules, social exclusion, racism and the lack of any social security. These smartphone-based transnational interactions serve as a 'legal order', regulating contractual relationships and obligations amongst migrants, exerting an identifiable impact on the outcomes of many practices Uzbek migrants (and other actors) engage in whilst in Moscow.

Eraliev and Heusala's chapter is an important contribution, primarily because it extends the scope of this volume to include the transnational experiences of Central Asian female migrants in Russia. Because the vast majority of migrants in Russia are male, the bulk of the literature on migration and informality in Russia has focused primarily on male-dominated transnational social spaces. Whilst the reasons prompting labour migration might be similar for both men and women, the consequences of migration can be drastically different for more vulnerable immigrant groups within migrant communities and, particularly, for women. Eraliev and Heusala argue that vulnerable migrant groups such as women often do not fit into transnationalism, informality or legal cultural narratives without taking into account the specificities of the female experience. To examine the transnational social spaces of Central Asian female migrants in Russia, the authors explored the life stories of four female migrants originating from Tajikistan and Uzbekistan, all residing in Moscow. In contrast to the previous chapter by Urinboyev, Eraliev and Heusala found that transnational social spaces did not include informed or equal choice for women. Informality, which includes multiple types of actors and reasons, currently sustains a transnational social space where the relatively well connected - typically, men - acquire rights and exercise these rights, whilst leaving other groups such as women and children in highly dependent positions. Female migrants as representatives of vulnerable migrant groups have limited opportunities to endure the precarious migrant life. They are not in a position to manoeuver around the official state structures using individualistic strategies. The revolving door migration between Central Asia and Russia, a lack of social capital and financial resources, their dependent position within migrant communities and strict family traditions limit the real agency of many female migrants. Instead of representing an empowering source of survival for female migrants, the current transnational social space in which Central Asian migrant women live recycles organisational pathologies of Russian authorities and the inequalities of their home countries. Thus, the decisions female migrants take regarding legal matters in Russia are often random, unpredictable and depend upon informal networks.

Mobile transnational actors not only carry their premigratory cultural repertoires, traditions and morality to their host country, but they can also reproduce their informal spiritual practices in their new environment. The transfer 
of unconventional healing practices from Tajikistan to the Russian Federation is at the heart of Cieslewska's contribution to this volume. Her chapter explores the development of the healing practices industry (such as writing amulets, divination, cupping therapy, etc.) in Russia. In doing so, she presents three case studies of migrant spiritual healers and/or religious leaders from Central Asia who perform spiritual services in Moscow. In particular, she examines how migrants create informal and formal spaces for expanding spiritual healing, and the ways in which those practices function in the local market as alternative medicine. Cieslewska argues that the informal nature of healing practices relates to the migrants' status in Moscow. That status also reflects the role and function of these healing methods within a particular spiritual tradition. Various healing practices have come to Russia with migrants from Central Asia as part of their religiosity, becoming services offered on the 'spiritual market' to migrants and nonmigrants. Transfer takes place primarily informally through trust networks and is embedded within social relations. Some migrants use the informal healing services as a coping strategy due to their limited access to medical care in Russia. They also view certain practices as part of their identity, which helps them in their experience as migrants by connecting them to their country of origin. In Moscow, the spiritual/ healing practices serve as a source of support for individuals, but also become a means to improving one's social position and increasing their income. Migrants find a niche amongst various alternative forms of healing, gradually changing the spiritual market in Russia. Their social and geographical dislocation also triggers their transformation, since they adapt to the local conditions and reformulate the meanings of their practices. Some of these meanings are transferred back to the countries of origin, influencing the local market for alternative healing practices.

Finally, Stanisz's chapter focuses on road regimes, where mobility created economic niches for a variety of actors in suburban Western Poland. Here, Stanisz draws upon an 'ethnographic study of roadside villages and towns located along Poland's national road no. 92, exploring how local and mobile people - that is, ordinary citizens, representatives of local governments, entrepreneurs, passing immigrants, road workers and truck drivers - adapt, change and maintain informal and/or semi-legal economic strategies'.

\section{Part III: Informality as state practice dealing with mobility}

The themes developed in the final section of this volume revolve around questions of bureacratising informality - in other words, formal machines with informal wheels. This section includes contributions that illustrate (a) how the state implements immigration control through various informal practices, a tactic that is essential for reconciling conflicting state priorities and practices, (b) informal practices surrounding border control and smuggling of migrants, (c) state services of health care or other services to provide citizens and migrants is obviously an ideal image of the state but not always a practice and (d) how the absence of viable formal legal channels incited minority groups to invent various informal practices outside the legal system. 
Schenk's chapter on symbolic and informal state practices 'demonstrates how formal and informal practices are not only a normal part of the state function, but they can be essential for reconciling conflicting state priorities and practices'. Here, she skilfully provides an insightful analysis of two policy mechanismsmigration quotas and deportation - within a surrounding package of policy and implementation practices. In doing so, Schenk shows that 'by selecting one key practice to elevate to the level of symbolic immigration control, state actors can absorb attention away from contradictions in the policy sphere that serve as evidence of ineffectiveness within the system'.

Virkkunen and Piipponen investigate an episode, the so-called 'Arctic route', through Moscow and Northern Russia, which became a major transit channel to the European Union (via Finland and Norway) during the 'migration crisis' of 2015 and 2016. Migrants from various Asian, African and Middle Eastern countries chose the Arctic route given its cheaper price and, significantly, because it was considered safer than the overcrowded route through the Mediterranean Sea to Greece, Italy and Spain. These new migratory flows were partly driven by extensive coverage in social and online media reports that spread rumours amongst migrant communities and smugglers in Russia and globally. Another key factor contributing to the emergence of the Arctic route was the informal practices of Russian state officials (e.g., corruption, the ambivalent behaviour of state authorities and ambiguous deportation orders) that served both as push and pull factors for migration. On the one hand, these informal practices created severe insecurities, pushing migrants to negotiate their daily survival by circumventing and exploiting state legal systems. On the other hand, a weak rule of law and a corrupt political system served as an opportunity structure and allowed smugglers, local businesses and migrants to establish the Arctic route. Russian state officials were indirectly involved in the operation of the Arctic route by allowing asylumseeking migrants with deportation orders to enter the usually well-guarded border zone in the North and to approach the Finnish and Norwegian borders. Migrants had their own agency, and, with help from intermediaries situated between migrants and the state, they were able to manage their trip to Finland and the European Union. In other words, because the informal practices functioned as the contextual foundation for migration in Russia and along the Arctic route, transnational and local intermediaries along with their contacts operated in order to negotiate concrete solutions and practices for migrants and the state bureaucracy alike. Without these, neither transnational migration nor the Arctic route would have been possible.

Following the disintegration of the Soviet Union in 1991, a different mode of mobility emerged. This mode is translocal, much more dynamic than the typical Soviet mode of mobility and characterised by its recurrence over individual lifespans. Kazakhstan's Oralmandar are a social category particularly affected by this post-Soviet form of mobility. As a people whose family networks and mobile lifestyles are often spread across several countries, healthcare systems, labour markets and jurisdictions, they are also especially affected by the respective regulatory frameworks in each of these areas. The chapter by Muratbayeva 


\section{Rano Turaeva and Rustamjon Urinboyev}

and Quasinowski describes the new practices related to informal healthcare services in rural Kazakhstan, which emerged in response to the new mobility of 'paperless' Oralmandar - that is, ethnic Kazakhs who immigrated from China and Uzbekistan to Kazakhstan in the post-Soviet period. Whilst from a strictly juridical point of view, 'paperless Oralmandar' are not legally entitled to treatment, in reality they have been provided with free primary healthcare services. These practices of informality tend to take on a complementary role to the formal healthcare provision, particularly in rural contexts, where regulatory frameworks are often inconsistent or entirely absent. However, these informal practices have been significantly affected by initiatives aimed at reforming and digitising Kazakhstan's healthcare system, requiring medical professionals to formally register and report each medical treatment they provide. Digitalisation no longer allows doctors to transgress regulatory frameworks and prevents them from providing free health care to the Oralmandar. As a result, rather than optimising and improving healthcare delivery, the digitalisation reforms introduced an element of arbitrariness into medical practitioners' decisionmaking, thereby leading to more informality and corruption within the healthcare sector. This example suggests that informality may usurp a complementary function alongside formal practices in spaces where the formal state policies and institutions are ineffective.

In the final chapter of this section, Yazdani investigates the informal practices of 'dual citizenship' amongst Meskhetian diasporic communities/return migrants in Georgia and Azerbaijan. The Meskhetian are an ethnic group that lived in villages along the Georgian-Turkish border until November 1944, when the Soviet army deported them en masse to Central Asia. Meskhetian Turks and their return to their historical homeland resulted from one of the main conditions Georgia needed to fulfil when negotiating its accession to the Council of Europe. Subsequently, when Georgia became a member of the Council in April 1999, the country accepted an official obligation and commitment to adopt legal measures to facilitate Meskhetian Turks' return to Georgia. Accordingly, in 2007, Georgia adopted the 'Law on the Repatriation of Persons Forcefully Resettled from Georgia by the Former Soviet Union in the 1940s', a legislative act specifically aimed at facilitating the return of Meskhetian Turks. However, this law provided insufficient time for submitting applications, imposed cumbersome requirements, left too much room for interpretation by government officials and contained many other legal requirements economically unfeasible barring their fulfilment. These legal barriers were further exacerbated by Georgia's new citizenship regime, which emphasised Orthodox Christianity and the Georgian language as primary markers of Georgian national identity. Meskhetians, a Turkish-speaking and Sunni Muslim people, thus became an 'internalised Orient' with little or no connection to mainstream Georgian society. Due to these hardships and legal uncertainties, Meskhetian Turk communities produced a myriad of informal practices and transnational lifestyles outside the nation-state's legal boundaries. Their daily lives feature an indisputable transnational quality and are based on family and kinship-driven trust networks, exhibited perhaps most comprehensively in family 
formation processes and in their eccentric relation to canonical, geographically sanctioned national identities.

\section{References}

Appadurai, A. 1991. "Global Ethnoscapes: Notes and Queries for a Transnational Anthropology." In Richard G. Fox (ed.), Recapturing Anthropology: Working in the Present. Santa Fe: School of American Research Press, 191-210.

Appadurai, A. 1996. Modernity at Large: Cultural Dimensions of Globalisation. Minneapolis: University of Minnesota Press.

Baldwin, Robert, Scott Collin and Christopher Hood (eds.) 1998. A Reader on Regulation. Oxford: Oxford University Press.

Beck, U. 2006. "Risk Society Revisited." In F. Cosgrave (ed.), The Sociology of Risk and Gambling Reader. London and New York: Routledge, 61-85.

Berliner, J.S. 1952. "The Informal Organization of the Soviet Firm." Quarterly Journal of Economics, 66(3), 342-365.

Boholm, A. 2003. "The Cultural Nature of Risk: Can There Be an Anthropology of Uncertainty?" Ethnos, 68(2), 159-178.

Butler, J. 2016. "Rethinking Vulnerability and Resistance." In Judith Butler, Zeynep Gambetti, and Leticia Sabsay (eds.), Vulnerability in Resistance. Durham: Duke University Press, 12-27.

Butler, J. 2006. Precarious Life: The Powers of Mourning and Violence. London and New York: Verso.

Cassel, Dieter and Ulrich Cichy 1986. "Explaining the Growing Shadow Economy in East and West: A Comparative System Approach." Comparative Economic Studies, 28, 20-41.

Chen, Martha A. 2006. "Rethinking the Informal Economy: Linkages with the Formal Economy and the Formal Regulatory Environment." In Basudeb Guha-Khasnobis, Ravi Kanbur and Elinor Ostrom (eds.), Linking the Formal and Informal Economy: Concept and Measures. Oxford: Oxford University Press, 75-92.

Cieślewska, A. 2014. "From Shuttle Trader to Businesswomen." In J. Morris and Abel Polese (eds.), The Informal Post-Socialist Economy: Embedded Practices and Livelihoods. New York: Routledge, 50-121.

Comaroff, John L. and Jean Comaroff 2006. "Introduction." In John L. Comaroff and Jean Comaroff (eds.), Law and Disorder in the Postcolony. Chicago: University of Chicago Press, 33.

Coutin, S.B. 2003. "Illegality, Borderlands, and the Space of Nonexistence.” In R.W. Perry and B. Maurer (eds.), Globalization Under Construction: Governmentality, Law, and Identity. Minneapolis: University of Minnesota Press, 171-202.

De Genova, N. 2004. "The Legal Production of Mexican/Migrant 'Illegality'." Latino Studies, 2(2), 160-185.

Djelic, Marie-Laure and Kerstin Sahlin-Andersson (eds.) 2006. Transnational Governance: Institutional Dynamics of Regulation. Cambridge: Cambridge University Press.

Eckert, Julia 2004. "Urban Governance and Emergent Forms of Legal Pluralism in Mumbai." Journal of Legal Pluralism, 36(50), 29-60.

Ewick, P. and S.S. Silbey 1992. "Conformity, Contestation, and Resistance: An Account of Legal Consciousness Symposium on Feminist Critical Legal Studies and 


\section{Rano Turaeva and Rustamjon Urinboyev}

Postmodernism: Part One: A Diversity of Influence.” New England Law Review, 26, 731-750.

Ewick, P. and S.S. Silbey 1998. The Common Place of Law: Stories from Everyday Life. London: University of Chicago Press.

Ewick, P. and S. Silbey 2003. "Narrating Social Structure: Stories of Resistance to Legal Authority." American Journal of Sociology, 108(6), 1328-1372.

Giddens, A. 1986. The Constitution of Society: Outline of the Theory of Structuration. Berkley: University of California Press.

Glick Schiller, N. and N.B. Salazar 2013. "Regimes of Mobility Across the Globe." Journal of Ethnic and Migration Studies, 39(2), 183-200.

Griffiths, J. 1992. "Legal Pluralism and the Social Working of Law." In B. Brouwer et al. (eds.), Coherence and Conflict in Law. Deventer/Boston-WEJ Tjeenk Willink Zwolle: Kluwer Law and Taxation Publishers, 151.

Grossman, Gregory 1977. "The 'Second Economy' of the USSR." Problems of Communism, 26(5), 25-40.

Hansen, Karen T. and Mariken Vaa (eds.) 2004. Reconsidering Informality: Perspectives from Urban Africa. Uppsala: North Africa Institute.

Humphrey, Caroline ed. 1998. Marx Went Away but Karl Stayed Behind. Ann Arbor: Michigan University Press.

Humphrey, Caroline 1999. 'Traders, 'Disorder,' and Citizenship Regimes in Provincial Russia." In Michael Burawoy and Katherine Verdery (eds.), Uncertain Transition: Ethnographies of Change in the Postsocialist World. Lanham, MD: Rowman and Littlefield, 19-52.

Hart, Keith 2005. Formal Bureaucracy and the Emergent Forms of the Informal Economy. WIDER Research Paper.

Hart, Keith 2008. Between Bureaucracy and the People: A Political History of Informality (No. 2008: 27). DIIS Working paper.

Kaiser, Markus 1997. Die Soziologie in der Republik Usbekistan. Bielefeld University Working Paper No. 265, Bielefeld, Germany.

Kotkin, Stephen 1995. Magnetic Mountain: Stalinism as a Civilization. Berkeley: University of California Press.

Ledeneva, Alena, V. 1998. Russia's Economy of Favours: Blat, Networking, and Informal Exchange. New York: Cambridge University Press.

Ledeneva, Alena, V. 2006. How Russia Really Works: Informal Practices in the 1990s. Ithaca, NY: Cornell University Press.

Ledeneva, Alena, V. 2013. Can Russia Modernize? Sistema, Power Networks and Informal Governance. Cambridge: Cambridge University Press.

Lefebvre, H. 2004. The Production of Space. Balden: Blackwell.

MacGaffey, J. and R. Bazenguissa-Ganga 2000. Congo-Paris: Transnational Traders on the Margins of the Law Transnational Traders on the Margins of the Law. Bloomington: Indiana University Press.

Maloney, William F. 2004. "Informality Revisited." World Bank Economic Review, 32(7), $1159-178$.

Markova, Mariana 2010. Living Through the Fall of Communism: Life Narratives of the Last Soviet Generation. Ph.D. Diss., University of Washington.

Mars, Gerald and Yochanan Altman 1983. "The Cultural Bases of Soviet Georgia's Second Economy." Europe-Asia Studies, 35(4), 546-560.

Marshall, A.-M. and S. Barclay 2003. "In Their Own Words: How Ordinary People Construct the Legal World." Law \& Social Inquiry, 28(3), 617-628. 
McBrien, J. 2013. "Afterword: In the Aftermath of Doubt." In Mathijs Pelkmans (ed.), Ethnographies of Doubt: Faith and Uncertainty in Contemporary Societies. London: IB Tauris, 251-268.

Meagher, Kate 2009. Culture Agency and Power: Theoretical Reflections on Informal Economic Networks and Political Process DIIS. Danish Institute for International Studies, Working Paper No. 2009-27, Copenhagen, Denmark.

Meagher, Kate 2010. "The Politics of Vulnerability: Exit, Voice, and Capture in Three Nigerian Informal Manufacturing Clusters." In Lindell Ilda (ed.), Africa's Informal Workers: Collective Agency, Alliances and Transnational Organizing in Urban Africa. London: Zed Books, 46-64.

Merry, S. E. 1988. "Legal Pluralism.” Law \& Society Review, 22, 869-896. .

Morris, J. and A. Barclay 2008. The Informal Post-Socialist Economy; Polese, Morris, and Kovács, "Introduction"; Round, John, Colin C. Williams and Peter Rodgers, "Everyday Tactics and Spaces of Power: The Role of Informal Economies in Post-Soviet Ukraine." Social \& Cultural Geography, 9(2), 171-185.

Mukhina, Irina 2009. "New Losses, New Opportunities: (Soviet) Women in the Shuttle Trade, 1987-1998." Journal of Social History, 43(2), 341-359.

Nazpary, Joma 2002. Post-Soviet Chaos: Violence and Dispossession in Kazakhstan. London: Pluto Press.

Pelkmans, Mathijs, eds. 2013. Ethnographies of Doubt: Faith and Uncertainty in Contemporary Societies. London: IB Tauris.

Pohorila, N. and G. Korzhov 2001. "Self-Identification in the Society of Crisis: A Case of Cross-Border Traders." Naykovi Zapiski Kievo-Mogilians 'koy akademiy, 19, 58-64.

Portes, Alejandro and József Böröcz 1988. "The Informal Sector under Capitalism and State Socialism: A Preliminary Comparison.” Social Justice, 15(3-4), 17-28.

Raeymaekers, T., K. Menkhaus and K. Vlassenroot 2008. "State and Non-State Regulation in African Protracted Crises: Governance Without Government?" Africa Focus, 21(2), $7-21$.

Roitman, Janet 2005. Fiscal Disobedience: An Anthropology of Economic Regulation in Central Africa. Princeton: Princeton University Press. Accessed June 23, 2020. doi:10.2307/j.ctv36zp9f.

Round, John Horace, Colin C. Williams and Peter Rodgers 2008. "Everyday Tactics and Spaces of Power: The Role of Informal Economies in Post-Soviet Ukraine." Social \& Cultural Geography, 9(2), 171-185.

Salazar, Noel B. 2017. "Key Figures of Mobility: An Introduction." Social Anthropology, 25(1), 5-12.

Salazar, Noel B. and Nina Glick Schiller (eds.). 2014. Regimes of Mobility: Imaginaries and Relationalities of Power. London: Routledge.

Samimian-Darash, L. 2012. "Governing Future Potential Biothreats: Toward an Anthropology of Uncertainty." Current Anthropology, 54(1), 1-22.

Schmidt, P. 2004. "Law in the Age of Governance: Regulation, Networks and Lawyers." In Jacint Jordana and David Levi-Faur (eds.), The Politics of Regulation: Institutions and Regulatory Reforms for the Age of Governance. Cheltenham: Edward Elgar, 273-295.

Silbey, S.S. 2005. "After Legal Consciousness." Annual Review of Law and Social Science, 1(1), 323-368.

Tanzi, Vito 1980. "Underground Economy and Tax Evasion in the United States: Estimates and Implication.” Banca Nazionale del Lavoro Quarterly Review, 32, 427-453.

Tokman, V.E. 1992. Beyond Regulation: The Informal Economy in Latin America. Boulder: Lynne Rienner. 


\section{Rano Turaeva and Rustamjon Urinboyev}

Treml, Vladimir G. and Michael V. Alexeev 1994. "The Growth of the Second Economy in the Soviet Union and its Impact on the System." In Robert W. Campbell (ed.), The Postcommunist Economic Transformation. Boulder, CO: Westview, 221-248.

Turaeva, Muyassar 2010. "Women's Health in Central Asia: The Case of Female Suitcase Traders." Anthropology of the Middle East, 5(2), 1-15.

Turaeva, Rano 2013. "Post-Soviet Uncertainties: Micro-orders of Central Asian Migrants in Russia.” Inner Asia, 15(2), 273-292.

Turaeva, Rano 2014. "Mobile Entrepreneurs in Post-Soviet Central Asia." Communist and Post-Communist Studies, 47(1), 105-114.

Turaeva, Rano 2016. Migration and Identity in Central Asia: The Uzbek Experience. Routledge.

Turaeva, Rano 2018. "Border and Road Regimes in Central Asia: Ordering Disorder at Uzbek-Kazakh Checkpoint." In Routledge Handbook of Asian Borderlands. Routledge, 434-444.

Urinboyev, R. 2017. "Establishing an 'Uzbek Mahalla' via Smartphones and Social Media: Everyday Transnational Lives of Uzbek Labor Migrants in Russia.” In M. Laruelle (ed.), Constructing the Uzbek State: Narratives of Post-Soviet Years. Boulder, CO: Lexington Books, 119-148.

Urinboyev, R. and A. Polese 2016. "Informality Currencies: A Tale of Misha, his Brigada and Informal Practices among Uzbek Labour Migrants in Russia." Journal of Contemporary Central and Eastern Europe, 24(3), 191-206.

Urry, J. 2012. Sociology Beyond Societies: Mobilities for the Twenty-first Century. London and New York: Routledge.

Urry, J. 2016. Mobilities: New Perspectives on Transport and Society. London and New York: Routledge.

von Benda-Beckmann, Franz and Julia Eckert (eds.) 2009. Rules of Law and Laws of Ruling: On the Governance of Law. Burlington, VT: Ashgate, 1-30.

von Benda-Beckmann, F., K. von Benda-Beckmann and J. Eckert 2009. Rules of law and laws of ruling: law and governance between past and future. Aldershot: Ashgate Publishing Limited. 